\title{
Red meat and egg intake and serum ferritin concentrations in Colombian children: results of a population survey, ENSIN-2015
}

\author{
Oscar F. Herran ${ }^{1}$ (D), Jhael N. Bermúdez ${ }^{2}$ and María Del Pilar Zea ${ }^{2,3}$ \\ ${ }^{1}$ Universidad Industrial de Santander, Bucaramanga, Santander, Colombia \\ ${ }^{2}$ Instituto Colombiano de Bienestar Familiar, Subdirección de Monitoreo y Evaluación, Bogotá, Colombia \\ ${ }^{3}$ Facultad de Ciencias de la Salud, Universidad Javeriana de Cali, Cali, Colombia
}

(Received 5 November 2019 - Final revision received 16 February 2020 - Accepted 19 February 2020)

Journal of Nutritional Science (2020), vol. 9, e12, page 1 of 11

doi:10.1017/jns.2020.5

\section{Abstract}

The present study aimed to (a) establish the frequency of consumption of red meat and eggs; (b) determine serum ferritin levels ( $\mu \mathrm{g} / \mathrm{l})$; and (c) establish the relationship between serum ferritin and the consumption of red meat and eggs. In Colombia during 2014-2018, an analytical study was conducted in 13 243 Colombian children between the ages of 5 and 17 years, based on cross-sectional data compiled by ENSIN-2015 (Encuesta Nacional de la Situación Nutricional en Colombia-2015) on serum ferritin levels and dietary consumption based on a questionnaire of the frequency of consumption. Using simple and multiple linear regression, with the serum ferritin level as the dependent variable and the frequency of consumption as the main explanatory variable, the crude and adjusted partial regression coefficients $(\beta)$ between serum ferritin levels and consumption were calculated. The frequency of habitual consumption of red meat was $0.49(95 \% \mathrm{CI} 0 \cdot 47,0.51)$ times/d. The frequency of habitual egg consumption was $0 \cdot 76(95 \% \mathrm{CI} 0 \cdot 74,0 \cdot 78)$ times per d. The mean serum ferritin level in men was 41.9 (95\% CI 40.6, 43.1) $\mu \mathrm{g} / 1$ and in women, $35 \cdot 7$ (95\% CI 34.3, 37.7) $\mu \mathrm{g} / 1(P<0 \cdot 0001)$. The adjusted $\beta$ between the consumption of red meat and eggs and serum ferritin levels were $\beta=3.0(95 \%$ CI $1 \cdot 2,4 \cdot 7)$ and $\beta=2.5(95 \%$ CI $1.0,3.9)$ for red meat and eggs, respectively. In conclusion, red meat and eggs are determinants of serum ferritin levels in Colombia and, therefore, could be considered public policy options to reduce anaemia and Fe deficiency.

Key words: Nutritional surveys: Ferritin: Eggs: Meat: Diet: Colombia

Serum ferritin (SF; $\mu \mathrm{g} / \mathrm{l})$ is a good indicator of body Fe deposits and is the most specific laboratory test to determine Fe deficiency $^{(1)}$. A low level without other abnormal results means depletion of $\mathrm{Fe}$ deposits $^{(1)}$, while elevated values (in adults) increase the risk of altered glucose homeostasis, insulin resistance syndrome and CVD in carriers of hereditary haemochromatosis $^{(2)}$. However, the concentration of SF may be falsely high as a consequence of an inflammatory response in acute processes or tissue damage in chronic processes ${ }^{(1-4)}$. According to the Food and Nutrition Board of the United
States National Academies of Sciences ${ }^{(5)}$, the dietary reference intakes of $\mathrm{Fe}$ range between 4.1 and $7.9 \mathrm{mg} / \mathrm{d}$ for the $4-17$ years age group $^{(5)}$. Fe present in animal-source foods is more bioavailable because it is found in its haem version, whose absorption is up to three times higher compared with non-haem $\mathrm{Fe}^{(1,5)}$. Red meat and eggs are part of the traditional dietary pattern of the Colombian population ${ }^{(6-8)}$, and the prevalence of consumption in a month for these two items is over $90 \%(9,10)$. In addition, they are sources of haem Fe: $100 \mathrm{~g}$ of red meat and eggs have 2.7 and $1.7 \mathrm{mg}$,

Abbreviations: ENSIN-2015, Encuesta Nacional de la Situación Nutricional en Colombia-2015 (National Survey of the Nutritional Situation of Colombia-2015); SF, serum ferritin.

* Corresponding author: Oscar F. Herran, fax +57 76323215, email herran@uis.edu.co; oscar.herran@gmail.com 
respectively ${ }^{(11)}$, which is equivalent to 34 and $21 \%$ of the recommended dietary intake/d for children between 5 and 17 years of age ${ }^{(5)}$.

According to the latest Encuesta Nacional de la Situación Nutricional en Colombia (National Survey of the Nutritional Situation of Colombia (ENSIN-2015)), Fe deficiency $(\mathrm{SF}<15 \mu \mathrm{g} / \mathrm{l})$ in children between 5 and 12 years of age was $8.8 \%$, and Fe-deficiency anaemia $(\mathrm{Hb}<120 \mathrm{~g} / \mathrm{l})$ was $17.7 \%$. In children between 13 and 17 years, deficiency was $10.3 \%$ and anaemia due to deficiency was $15.3 \%(\mathrm{Hb}<120 \mathrm{~g} / \mathrm{l}$ in women and $\mathrm{Hb}<130 \mathrm{~g} / 1$ in men), figures that are considered public nutrition issues ${ }^{(10,12)}$; this situation is common in developing countries ${ }^{(13)}$. Anaemia is the best-known consequence of all those resulting from $\mathrm{Fe}$ deficiency, but decreased muscle strength and ability to work ${ }^{(14)}$, along with altered immune system and inability to regulate body temperature, are also common $^{(15,16)}$. These are the most relevant outcomes at an early age but, in the long term, behavioural alterations and irreparable cognitive deficits in children may be observed ${ }^{(17-19)}$.

Prevalence of usual consumption of red meat and eggs greater than $90 \%$ confirm that the goal set for 2015 in the National Development Plan (Plan Nacional de Desarrollo (PND)) Colombia 2014-2018 was reached ${ }^{(20)}$, although the recommendation to increase the percentage of people who consume meat and eggs on a daily basis should technically be understood as increasing the frequency/d of consumption rather than the prevalence. Furthermore, the Food-Based Dietary Guidelines for the Colombian population over 2 years of age ${ }^{(21)}$ also make explicit recommendations on consumption: eating one egg, milk and dairy products daily. Although both documents recommend increasing the consumption of these foods, they do so from the perspective of sources of protein and not haem Fe.

The present study was proposed given that anaemia and $\mathrm{Fe}$ deficiency are endemic problems in the Colombian population and have devastating effects on children and on productivity in general. The objectives were: (a) to establish the frequency of red meat and egg consumption (times/d); (b) to determine SF levels among red meat and egg consumers; and (c) to establish the degree of relationship between SF and red meat and egg consumption in the population aged 5-17 years in Colombia.

\section{Materials and methods}

The present analytical study is based on cross-sectional data collected in 2015-2016 by the ENSIN-2015 regarding SF levels $(\mu \mathrm{g} / \mathrm{l})$ and dietary consumption, using an FFQ.

\section{Study population}

The ENSIN-2015 $5^{(9,10)}$ was carried out during the past 4 years in Colombia. In short, these surveys are designed to represent $99 \%$ of the population through stratified multistage sampling. All thirty-three geodemographic units or departments are grouped based on similar geographic and sociodemographic characteristics. The municipalities in these units are randomly selected and form strata with a probability proportional to the size of the population. Clusters of approximately ten households are randomly selected within these strata and household members are invited to participate. The ENSIN-2015 included 44202 households, which represented 4739 clusters of 177 strata. Consent to participate was obtained during the field operation.

\section{Population and sample}

The ENSIN-2015 included 151343 people. The FFQ was applied to 28903 subjects, of whom 14092 were between 5 and 17 years old; they were inquired about their usual food intake in the last $30 \mathrm{~d}$. SF levels were obtained in 41439 subjects, of whom 36978 were between 5 and 17 years old. A total of 28253 subjects consumed two of the thirty-nine food items included in the FFQ, that is 'Eggs' and 'Beef, veal, pork, capybara, rabbit, goat, domestic guinea pig' - called red meat for the purposes of this study. The target population was redefined through subpopulations of interest. The first subpopulation was composed of children between 5 and 17 years old, consumers of red meat, who will not try any type of diet by medical prescription, without pregnancy, and with size $\geq 80 \mathrm{~cm}$ and size $<200 \mathrm{~cm}$ and weight $\geq 12 \mathrm{~kg}$ and weight $<200 \mathrm{~kg}$ in order to guarantee plausible data of nutritional status; this subpopulation included 12106 children. The second subpopulation was defined as children between 5 and 17 years old, egg consumers, who will not try any type of diet by medical prescription, without pregnancy, and with size $\geq 80 \mathrm{~cm}$ and size $<200 \mathrm{~cm}$ and weight $\geq 12 \mathrm{~kg}$ and weight $<200 \mathrm{~kg}$ in order to guarantee plausible data of nutritional status; this subpopulation was made up of 12702 children. Finally, a third subpopulation was established with the same characteristics described above, which allowed studying the children who usually consumed: (a) red meat and eggs; (b) red meat but not eggs; (c) no red meat but eggs; and (d) neither one; this subpopulation comprised 13243 children. Since FFQ and SF data were obtained from different subsamples, 10260 children had SF data in the red meat consumers group, 10764 in the egg consumers group, and 16582 in the red meat and egg consumers group.

\section{Data sources}

Trained staff administered questionnaires to household heads to obtain information on sociodemographics, food security and level of wealth of the household. In addition, nutritionists applied in randomly selected subsamples an FFQ for the last month, with nine categories to establish the frequency of usual food intake. Children under the age of 12 years were assisted by their caregivers to respond to the FFQ. The food and food group checklist was designed by nutritionists based on the nutrition problems identified in past $\operatorname{ENSIN}^{(9,10)}$ and other sources. The list of items related to the response to frequency of consumption was adapted from two reproducibility and validity studies from other FFQ conducted in the Colombian population ${ }^{(22,23)}$. Face validity was guaranteed for all items on the checklist. The FFQ methodology is in nutritional epidemiology the most used in the world. The measurement with an FFQ allows estimating 
the prevalence of consumption and its frequency in terms of times/d. These two indicators of consumption are good estimators of the amount consumed (g). Establishing the amount (g) of consumption through other methods, such as the 24-h recall or diet record methods, is complex and very expensive, which makes it unfeasible ${ }^{(22,23)}$.

Anthropometric measurements were also taken by trained nutritionists and surveyors, using standardised techniques and calibrated equipment. Size was established using a portable measuring rod (Shorr Board Productions LCC), approaching the nearest $1 \mathrm{~mm}$. Weight was established with SECA scales (model 874), approximating to $100 \mathrm{~g}$. The nine responses in the FFQ on the frequency of consumption of these two food items were converted to a continuous variable, 'times/d'.

SF levels were established in a random subsample of participants; for this purpose, blood was drawn by venepuncture from the median cubital vein. One sample was collected in an EDTA tube for plasma separation and another in a metal-free polypropylene tube without anticoagulant for serum separation. All samples were stored in liquid $\mathrm{N}_{2}$ until their processing at the National Health Institute (Instituto Nacional de Salud) of Colombia. Plasma ferritin was quantified in children aged 5 to 17 years using a competitive chemiluminescent immunoassay on an ADVIA Centaur analyser (Siemens HealthCare Diagnostics, Inc.). Plasma C-reactive protein (PCR) was quantified by turbidimetry in an ACS-180 analyser (Siemens Healthcare Diagnostics, Inc.). Since there is evidence of high SF values when there is acute or chronic inflammation ${ }^{(1-4)}$, and to ensure the plausibility of the results, the ENSIN-2015 corrected the SF values by the PCR level in children between 5 and 17 years old $\left(\mathrm{SF}=\mathrm{SF}_{\text {original }}-15\right.$, if PCR $>0 \cdot 5)$.

The variables of interest were the frequency of usual consumption (times/d) of red meat, eggs and the SF level. The two FFQ items 'Eggs' and 'Beef, veal, pork, capybara, rabbit, goat, domestic guinea pig' were chosen because of their high consumption prevalence and because they are sources of haem $\mathrm{Fe}$. Moreover, $\mathrm{SF}$ was preferred to $\mathrm{Hb}$, which is a protein used as a biomarker of $\mathrm{Fe}$ stores and $\mathrm{Fe}$ nutrition. Other covariates were also considered to correlate them with dietary intake and SF levels: sex, age, size, BMI - and its equivalent according to the International Obesity Task Force $(\mathrm{IOTF})^{(24,25)}-$, state of food security in the household, wealth index, ethnicity, level of urbanism and the geographical region where the subjects live. The level of urbanism refers to people living in urban areas, including large cities. The rural category included suburban population centres close to small cities, municipal seats distant from small cities, and populations scattered or very distant from municipal seats. Household food security status was established using the Latin American and Caribbean Food Security (ELCSA) scale ${ }^{(9)}$.

On the other hand, wealth was established based on the index designed for the international Demographic and Health Survey ${ }^{(26)}$. This index was constructed through the analysis of main components based on household information, which included, among others, the type of construction material of the dwelling, the characteristics of the health services and, in general, the goods and services available in the household. The first component is used to create the index as a continuous variable (z-score), which is assigned to each subject within the household. The highest values represent the richest subjects. The wealth index was categorised by incorporating the complex sample design into quintiles according to the distribution achieved among all survey participants. The geographical region grouped several geodemographic units and, in general, they share the most relevant aspects of food culture ${ }^{(27)}$.

\section{Data processing and statistical analysis}

All analyses were conducted using the analysis plan for complex sample designs of Stata software, version $14.1^{(28)}$. The analysis was conducted to estimate the average frequency of usual consumption (times/d) of red meat and eggs, with their corresponding $95 \% \mathrm{CI}$, in the population of children aged 5 to 17 years and for each of the categories of covariates of interest. Using simple and multiple linear regression, having SF level as the dependent variable and consumption frequency as the main explanatory variable, crude and adjusted partial regression coefficients $(\beta)$ were estimated - direction and strength of the association (correlation) - between the SF levels and the consumption frequency. In addition, adjusted differences between $\beta$ were estimated for each of the covariate categories. To obtain the adjusted differences, a new term was created as the cross-product between frequency/d and SF level for each category of covariates (interaction). The adjusted differences and their corresponding 95\% CI incorporated the complex sample design and the multiple regression models included the following covariates: sex, age, stunted growth, BMI, food security level, wealth index, ethnicity, level of urbanism and region. Finally, using multiple linear regressions, crude and adjusted means and their corresponding 95\% CI were estimated for the SF levels in the consumption categories of the third subpopulation described above.

\section{Ethical considerations}

All analyses were carried out under the principles of the Helsinki Declaration ${ }^{(29)}$. The used databases are in the public domain. This research is classified as 'without risk' according to Resolution 8430 of 1993 of the Colombian Ministry of Health $^{(30)}$. Since this is a secondary analysis of population studies, with anonymised data, no authorisation is required from the Health Research Ethics Committee of the Industrial University of Santander.

\section{Results}

The prevalence of red meat consumption was $93.3(95 \% \mathrm{CI}$ $92 \cdot 4,94 \cdot 1) \%$, with no difference by sex $(P=0.809)$. The prevalence of egg consumption was $96.6(95 \%$ CI $96 \cdot 0$, $97 \cdot 1) \%$, with no difference by sex $(P=0 \cdot 174)$. The mean frequency of usual red meat consumption was $0.49(95 \%$ CI $0.47,0.51)$ times/d, with no difference by sex $(P=0.764)$. The mean frequency of usual egg consumption was 0.76 $(95 \%$ CI $0.74,0.78)$ times/d, with no difference by sex $(P$ $=0 \cdot 890)$. The mean SF was $38.9(95 \%$ CI $38 \cdot 0,39 \cdot 9) \mu \mathrm{g} / \mathrm{l}$; 


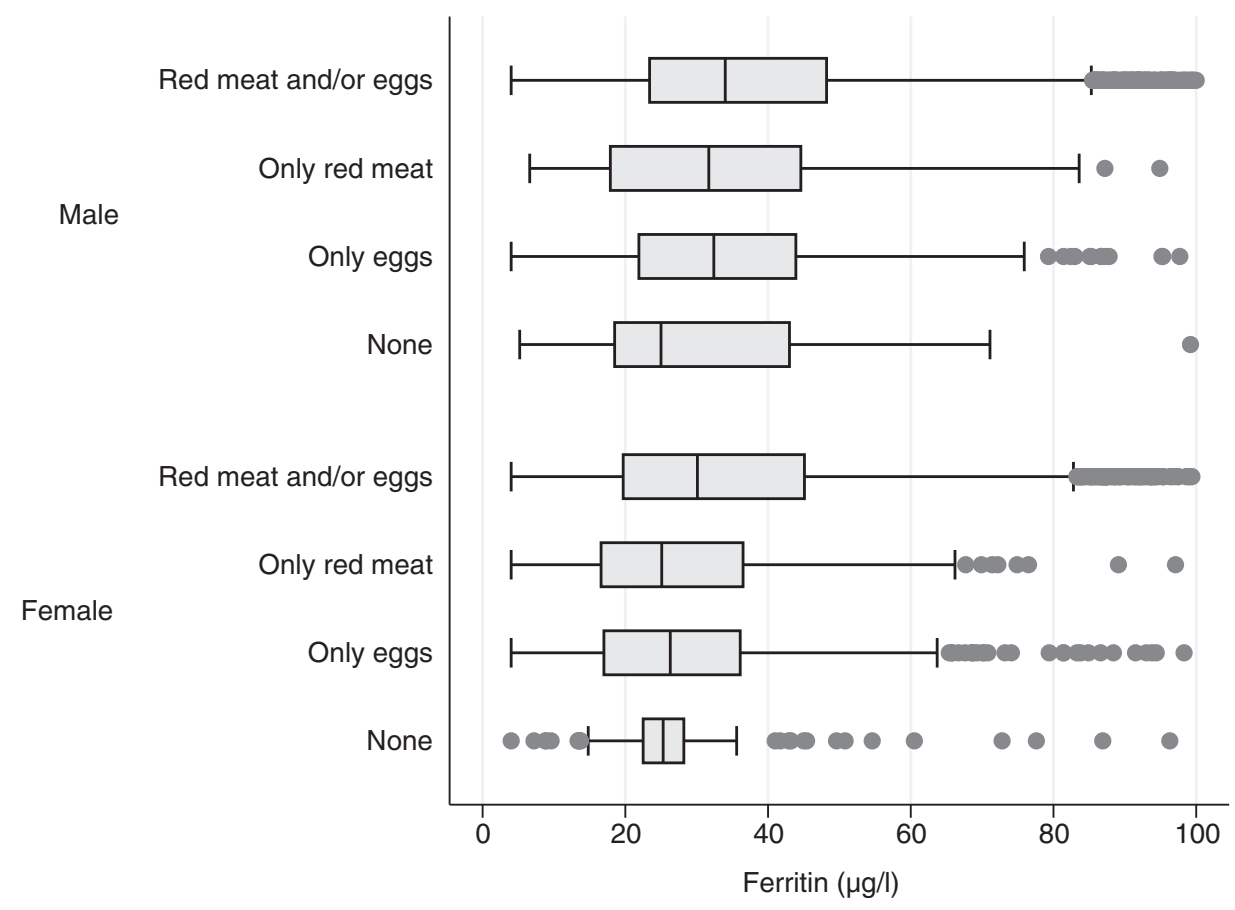

Fig. 1. Serum ferritin levels in children between 5 and 17 years of age according to red meat and egg consumption, Colombia, ENSIN-2015 (Encuesta Nacional de la Situación Nutricional en Colombia-2015; National Survey of the Nutritional Situation of Colombia-2015). The line inside the box represents the median (quartile 2; Q2). The edges of the box represent quartile 1 (Q1) and quartile 3 (Q3), respectively. The limits of the whiskers represent up to 1.5 times the interquartile range (IQR = Q3 - Q1): Q1 - 1.5 or Q3 + 1.5. The points to the right and left represent extreme atypical values.

$41.9(95 \%$ CI $40 \cdot 6,43 \cdot 1) \mu \mathrm{g} / 1$ in men and $35 \cdot 7(95 \%$ CI $34 \cdot 3$, $37.7) \mu \mathrm{g} / 1$ in women. This difference of $6 \cdot 2 \mu \mathrm{g} / 1$ against women is statistically significant $(P<0 \cdot 0001)$. The proportion of children who ate red meat and/or eggs was 90.6 (95\% CI $89 \cdot 5,91 \cdot 5) \%$, in the first category of the third subpopulation; more specifically, it was $2 \cdot 7$ (95\% CI $2 \cdot 3,3 \cdot 2) \%$ for children who only ate meat, $6.0(95 \%$ CI $5.3,6.9) \%$ for children that only ate eggs, and $0.6(95 \% \mathrm{CI} 0.4,1 \cdot 0) \%$ for children who do not eat meat or eggs. Among meat and/or egg consumers, the average SF was $39.4(\mathrm{SE} 0.5) \mu \mathrm{g} / \mathrm{l}$; among meat-only consumers $36 \cdot 2$ (SE $2 \cdot 0$ ) $\mu \mathrm{g} / \mathrm{l}$; among egg-only consumers $34 \cdot 5$ (SE 1.1) $\mu \mathrm{g} / \mathrm{l}$; and among those who do not eat meat nor eggs $34 \cdot 2$ (SE 1.5) $\mu \mathrm{g} / 1\left(\chi^{2}\right.$ for trend, $\left.P \leq 0 \cdot 0001\right)$ (Fig. 1).

The daily frequency of red meat consumption (times/d) was lower among those with stunted growth, as food insecurity increased, among black/Afro-descendant and indigenous populations, in rural areas and in all regions compared with the central region. SF $(\mu \mathrm{g} / \mathrm{l})$ levels among meat consumers were lower in women, as food insecurity increased, in the black/Afro-descendant population, and in all regions compared with the central region, except in the Eastern and Atlantic regions (Table 1). The frequency of egg consumption (times/d) was lower among overweight children and in all regions compared with the central region. Egg consumption was higher as the wealth index increased. SF levels among egg consumers were lower in women, in the black/Afro-descendant population and in the Atlantic, Pacific and Amazon/Orinoquia regions. Children who were overweight and obese had higher levels of SF than those classified as normal (Table 2).

Tables 3 and 4 present the raw and adjusted $\beta$-coefficients between red meat and egg consumption (times/d) and SF levels $(\mu \mathrm{g} / \mathrm{l})$. The correlation between red meat and egg consumption and SF levels is evident: $\beta=3.0$ (95\% CI 1.2 , $4.7)$ and $\beta=2.5(95 \%$ CI $1.0,3.9)$ for red meat and eggs, respectively. There were no differences in the correlations adjusted by the categories of the variables studied, except for Bogotá, where the correlation between egg consumption and SF levels was 5.4 times higher than the mean correlation in the general population ( $\beta=13.4(95 \%$ CI $5 \cdot 5,21 \cdot 3)$; Table 4). Fig. 2 shows how SF levels increase as the frequency of meat and eggs consumption increases.

\section{Discussion}

It could be established that, in children between 5 and 17 years of age in Colombia, the average frequency (times/d) of usual consumption of red meat is lower than the consumption of eggs. Red meat is consumed every $2 \mathrm{~d}$, while two eggs are consumed every $3 \mathrm{~d}$. In addition, the prevalence of red meat and egg consumption is high, above $95 \%$, and combined is greater than $90 \%$. However, in order to meet the consumption/d targets established in the National Development Plan (Plan Nacional de Desarrollo (PND)) ${ }^{(20)}$ and the Food-Based Dietary Guidelines ${ }^{(21)}$, the average frequency of red meat consumption among the population should be doubled - by 100 $\%$ - and egg consumption should be increased by at least 25 $\%$. SF levels are very similar among meat and egg consumers; however, meat and/or egg consumers, who are the majority, have higher SF levels than consumers of one of the two foods exclusively (Fig. 1). The correlation between frequency of red meat and egg consumption is similar and statistically significant, which corroborated that these foods are determinants of SF levels and are, therefore, public policy options to decrease anaemia and Fe deficiency. 
Table 1. Red meat consumption (times/d) and serum ferritin levels ( $\mu \mathrm{g} / \mathrm{l})$ among red meat consumers in a population between 5 and 17 years of age, Colombia, ENSIN-2015

(Mean values with their standard errors; differences and $95 \%$ confidence intervals)

\begin{tabular}{|c|c|c|c|c|c|c|c|c|c|c|c|}
\hline \multirow[b]{2}{*}{ Variable } & \multirow[b]{2}{*}{$n$} & \multicolumn{5}{|c|}{ Red meat (times/d) (n 12 106) } & \multicolumn{5}{|c|}{ Serum ferritin $(\mu \mathrm{g} / \mathrm{l})(n 10260)$} \\
\hline & & Mean & SE & Difference & $95 \% \mathrm{Cl}$ & $P$ & Mean & SE & Difference & $95 \% \mathrm{Cl}$ & $P$ \\
\hline Total & 12106 & 0.49 & 0.01 & & & & $39 \cdot 2$ & 0.50 & & $38 \cdot 2,40 \cdot 3$ & \\
\hline \multicolumn{12}{|l|}{ Sex } \\
\hline Male & 6206 & 0.49 & 0.01 & Ref & & Ref & $42 \cdot 1$ & 0.66 & Ref & & Ref \\
\hline Female & 5900 & 0.49 & 0.01 & -0.00 & $-0.03,0.02$ & 0.764 & $35 \cdot 9$ & 0.63 & $-6 \cdot 25$ & $-7 \cdot 87,-4.63$ & $<0.0001$ \\
\hline \multicolumn{12}{|l|}{ Age group (years) } \\
\hline Children $(5-10)$ & 4176 & 0.48 & 0.01 & Ref & & Ref & $39 \cdot 4$ & 0.76 & Ref & & Ref \\
\hline Adolescents (11-17) & 7930 & 0.50 & 0.01 & 0.02 & $-0.01,0.05$ & $0 \cdot 149$ & $39 \cdot 1$ & $0 \cdot 61$ & -0.24 & $-2 \cdot 10,1 \cdot 62$ & 0.798 \\
\hline \multicolumn{12}{|l|}{ Age (years) } \\
\hline $5-8$ & 2948 & 0.49 & 0.02 & Ref & & Ref & 37.7 & 0.87 & Ref & & Ref \\
\hline $9-11$ & 1903 & 0.46 & 0.02 & -0.03 & $-0.07,0.00$ & 0.066 & $40 \cdot 4$ & 0.99 & $2 \cdot 66$ & $0 \cdot 29,5 \cdot 01$ & 0.028 \\
\hline $12-15$ & 4626 & 0.50 & 0.01 & 0.01 & $-0.03,0.04$ & 0.664 & 36.9 & 0.74 & -0.80 & $-3 \cdot 05,1.45$ & 0.479 \\
\hline $16-17$ & 2629 & 0.52 & 0.01 & 0.03 & $-0.01,0.07$ & 0.131 & $45 \cdot 6$ & $1 \cdot 12$ & $7 \cdot 87$ & $4 \cdot 89,10 \cdot 85$ & $<0.0001$ \\
\hline \multicolumn{12}{|l|}{ Stunted growth $(\mathrm{H} / \mathrm{A})$} \\
\hline No & 11067 & 0.50 & 0.01 & Ref & & Ref & $39 \cdot 3$ & 0.53 & Ref & & Ref \\
\hline Yes $(z<2)$ & 1035 & 0.44 & 0.02 & -0.05 & $-0.10,-0.01$ & 0.021 & $39 \cdot 0$ & $1 \cdot 27$ & -0.27 & $-2 \cdot 94,2 \cdot 40$ & 0.839 \\
\hline \multicolumn{12}{|l|}{ Nutritional status (BMI)* } \\
\hline No & 10110 & 0.49 & 0.01 & Ref & & Ref & 38.4 & 0.54 & Ref & & Ref \\
\hline Overweight $\left(\geq 25 \mathrm{~kg} / \mathrm{m}^{2}\right)$ & 1546 & 0.48 & 0.02 & -0.01 & $-0.04,0.03$ & 0.753 & $42 \cdot 7$ & $1 \cdot 17$ & $4 \cdot 24$ & $1.79,6.70$ & 0.001 \\
\hline Obese $\left(\geq 30 \mathrm{~kg} / \mathrm{m}^{2}\right)$ & 450 & 0.55 & 0.04 & $0 \cdot 10$ & $-0.02,0.14$ & $0 \cdot 131$ & $45 \cdot 2$ & $2 \cdot 63$ & $6 \cdot 75$ & $1 \cdot 40,12 \cdot 10$ & 0.014 \\
\hline \multicolumn{12}{|l|}{ Food insecurity $\dagger$} \\
\hline No & 3855 & 0.56 & 0.01 & Ref & & Ref & $41 \cdot 1$ & 0.88 & Ref & & Ref \\
\hline Mild & 4355 & 0.50 & 0.01 & -0.06 & $-0.10,-0.02$ & 0.002 & 37.9 & $0 \cdot 68$ & $-3 \cdot 23$ & $-5.46,-1.01$ & 0.005 \\
\hline Moderate & 2260 & 0.44 & 0.02 & -0.12 & $-0.17,-0.07$ & $<0.0001$ & 39.7 & 0.99 & -1.43 & $-3.94,1.08$ & 0.259 \\
\hline Severe & 1636 & 0.38 & 0.02 & -0.18 & $-0.22,0.14$ & $<0.0001$ & $37 \cdot 8$ & $1 \cdot 35$ & $-3 \cdot 27$ & $-6.46,-0.07$ & 0.045 \\
\hline \multicolumn{12}{|l|}{ Wealth index } \\
\hline$Q_{1}-$ the poorest & 2393 & 0.46 & 0.03 & Ref & & Ref & $39 \cdot 1$ & 1.47 & Ref & & Ref \\
\hline$Q_{2}$ & 2548 & 0.48 & 0.02 & 0.01 & $-0.04,0.07$ & 0.568 & $37 \cdot 8$ & 0.92 & $-1 \cdot 34$ & $-4.63,1.94$ & 0.417 \\
\hline $\mathrm{Q}_{3}$ & 2570 & 0.46 & 0.02 & -0.00 & $-0.07,0.06$ & 0.984 & $39 \cdot 0$ & 1.02 & -0.18 & $-3.74,3.38$ & 0.919 \\
\hline $\mathrm{Q}_{4}$ & 2384 & 0.48 & 0.01 & 0.02 & $-0.04,0.08$ & 0.547 & $39 \cdot 4$ & 0.93 & 0.29 & $-3 \cdot 10,3 \cdot 69$ & 0.864 \\
\hline$Q_{5}$ - the richest & 2211 & 0.55 & 0.02 & 0.08 & $0.02,0.15$ & 0.017 & $40 \cdot 3$ & 1.00 & $1 \cdot 17$ & $-2 \cdot 35,4 \cdot 70$ & 0.508 \\
\hline \multicolumn{12}{|l|}{ Ethnicity } \\
\hline Mestizo & 9930 & 0.51 & 0.01 & Ref & & Ref & 39.7 & 0.54 & Ref & & \\
\hline Black/Afro-descendant & 1061 & 0.40 & 0.04 & -0.11 & $-0.18,-0.04$ & 0.003 & $33 \cdot 1$ & 2.90 & $-6 \cdot 52$ & $-12 \cdot 43,-0.62$ & 0.031 \\
\hline Indigenous & 1022 & 0.38 & 0.02 & -0.13 & $-0.17,-0.08$ & $<0.0001$ & $38 \cdot 6$ & 1.44 & -1.06 & $-4 \cdot 12,2 \cdot 00$ & 0.492 \\
\hline \multicolumn{12}{|l|}{ Area } \\
\hline Urban & 8896 & 0.48 & 0.01 & 0.03 & $-0.01,0.07$ & $0 \cdot 187$ & $39 \cdot 3$ & 0.55 & Ref & & Ref \\
\hline Rural & 3210 & 0.51 & 0.02 & 0.48 & $0.46,0.50$ & $<0.0001$ & $39 \cdot 2$ & 1.03 & -0.09 & $-2 \cdot 35,2 \cdot 17$ & 0.937 \\
\hline \multicolumn{12}{|l|}{ Region } \\
\hline Central & 2961 & 0.63 & 0.03 & Ref & & & 39.9 & 0.82 & Ref & & Ref \\
\hline Atlantic & 2242 & 0.38 & 0.01 & -0.25 & $-0.31,-0.19$ & $<0.0001$ & 35.4 & 1.09 & -4.52 & $-7.25,-1.79$ & 0.002 \\
\hline Eastern & 2134 & 0.55 & 0.02 & -0.08 & $-0.15,-0.01$ & 0.032 & $43 \cdot 8$ & 1.27 & 3.92 & $0.90,6.94$ & 0.012 \\
\hline Pacific & 1490 & 0.43 & 0.02 & -0.20 & $-0.27,-0.13$ & $<0.001$ & $35 \cdot 7$ & 0.97 & $-4 \cdot 17$ & $-6 \cdot 71,-1.62$ & 0.002 \\
\hline Bogotá & 833 & 0.47 & 0.02 & -0.15 & $-0.22,-0.08$ & $<0.001$ & $45 \cdot 1$ & 1.41 & $5 \cdot 25$ & $1.98,8.52$ & 0.002 \\
\hline Amazon/Orinoquia & 2446 & 0.46 & 0.02 & -0.17 & $-0.24,-0.10$ & $<0.001$ & $35 \cdot 8$ & 1.40 & -4.06 & $-7 \cdot 31,-0.81$ & 0.015 \\
\hline
\end{tabular}

ENSIN-2015, Encuesta Nacional de la Situación Nutricional en Colombia-2015 (National Survey of the Nutritional Situation of Colombia-2015); Ref, reference; H/A, height for age; $Q$, quintile.

* Based on BMI equivalents according to the International Obesity Task Force.

† Based on the Latin American and Caribbean Food Security (ELCSA) Scale.

The mean frequency of red meat consumption was lower in children with stunted growth (chronic malnutrition), and inversely correlated to the levels of food insecurity in the household, in the indigenous and black/Afro-descendant ethnic groups, in the rural area and in all regions when compared with the central region. This finding may be explained to a large extent by the monetary poverty associated with undernourished individuals or ethnic minorities and, also, with a lower structural development in the peripheral regions or their proximal variables such as the rural area ${ }^{(31-37)}$. Having meat on the table requires a greater relative cost than that needed to have eggs, besides physical infrastructure to ensure the cold chain and others required for slaughter, which makes meat production more complex and costly. More precisely and based on red meat and egg prices in November 2018, $1 \mathrm{~g}$ of Fe derived from meat costs at least 1.5 times more than one egg derivative.

Red meat, according to the WHO through the International Agency for Research on Cancer (IARC) ${ }^{(38,39)}$, was classified as a group 2A agent: probable carcinogen. The dose (portion + frequency/d) of red meat consumed in Colombia by children between 5 and 17 years of age, according to the ENSIN-2005, was $54 \mathrm{~g}$ - average estimate derived from the current intake through the $24-\mathrm{h}$ dietary recall $^{(9)}-$, and the frequency/d 
Table 2. Egg consumption (times/d) and serum ferritin levels $(\mu \mathrm{g} / \mathrm{l})$ among egg consumers in a population between 5 and 17 years of age, Colombia, ENSIN-2015

(Mean values with their standard errors; differences and $95 \%$ confidence intervals)

\begin{tabular}{|c|c|c|c|c|c|c|c|c|c|c|c|}
\hline \multirow[b]{2}{*}{ Variable } & \multirow[b]{2}{*}{$n$} & \multicolumn{5}{|c|}{ Eggs (times/d) ( $n$ 12 702) } & \multicolumn{5}{|c|}{ Serum ferritin $(\mu \mathrm{g} / \mathrm{l})(n 10764)$} \\
\hline & & Mean & SE & Difference & $95 \% \mathrm{Cl}$ & $P$ & Mean & SE & Difference & $95 \% \mathrm{Cl}$ & $P$ \\
\hline Total & 12702 & 0.76 & 0.01 & & & & $39 \cdot 0$ & 0.49 & & & \\
\hline \multicolumn{12}{|l|}{ Sex } \\
\hline Male & 6521 & 0.76 & 0.01 & Ref & & & $42 \cdot 0$ & 0.64 & Ref & & Ref \\
\hline Female & 6181 & 0.75 & 0.01 & -0.00 & $-0.04,0.03$ & 0.890 & $35 \cdot 6$ & 0.61 & $-6 \cdot 38$ & $-7.97,-4.78$ & $<0.001$ \\
\hline \multicolumn{12}{|l|}{ Age group (years) } \\
\hline Children (5-10) & 4485 & 0.75 & 0.01 & Ref & & Ref & $39 \cdot 4$ & 0.76 & Ref & & Ref \\
\hline Adolescents (11-17) & 8217 & 0.76 & 0.01 & 0.01 & $-0.02,0.05$ & 0.485 & $39 \cdot 1$ & 0.61 & -0.39 & $-2 \cdot 20,1 \cdot 42$ & 0.665 \\
\hline \multicolumn{12}{|l|}{ Age (years) } \\
\hline $5-8$ & 3171 & 0.76 & 0.01 & Ref & & Ref & 37.7 & 0.87 & Ref & & Ref \\
\hline $9-11$ & 2036 & 0.74 & 0.02 & -0.02 & $-0.07,0.02$ & 0.292 & $40 \cdot 4$ & 0.99 & $2 \cdot 46$ & $0.21,4.71$ & 0.033 \\
\hline $12-15$ & 4827 & 0.76 & 0.02 & -0.00 & $-0.04,0.04$ & 0.930 & 36.9 & 0.74 & -0.64 & $-2 \cdot 84,1 \cdot 56$ & 0.564 \\
\hline $16-17$ & 2668 & 0.78 & 0.02 & 0.02 & $-0.02,0.07$ & 0.323 & $45 \cdot 6$ & $1 \cdot 12$ & $7 \cdot 64$ & $4.73,10.54$ & $<0.0001$ \\
\hline \multicolumn{12}{|l|}{ Stunted growth $(H / A)$} \\
\hline No & 11557 & 0.75 & 0.01 & Ref & & Ref & $39 \cdot 3$ & 0.53 & Ref & & Ref \\
\hline Yes $(z<2)$ & 1140 & 0.74 & 0.04 & -0.01 & $-0.10,0.07$ & 0.748 & 39.0 & $1 \cdot 27$ & -1.03 & $-3.53,1.4$ & 0.412 \\
\hline \multicolumn{12}{|l|}{ Nutritional status $(\mathrm{BMI})^{\star}$} \\
\hline No & 10611 & 0.76 & 0.01 & Ref & & Ref & 38.4 & 0.54 & Ref & & Ref \\
\hline Overweight $\left(\geq 25 \mathrm{~kg} / \mathrm{m}^{2}\right)$ & 1629 & 0.71 & 0.02 & -0.05 & $-0.09,-0.00$ & 0.034 & $42 \cdot 7$ & $1 \cdot 17$ & 4.04 & $1 \cdot 66,6 \cdot 44$ & 0.001 \\
\hline Obese $\left(\geq 30 \mathrm{~kg} / \mathrm{m}^{2}\right)$ & 462 & $0 \cdot 81$ & 0.04 & 0.06 & $-0.03,0.14$ & $0 \cdot 215$ & $45 \cdot 2$ & $2 \cdot 63$ & $6 \cdot 96$ & $1.49,12 \cdot 42$ & 0.013 \\
\hline \multicolumn{12}{|l|}{ Food insecurity $†$} \\
\hline No & 3973 & 0.76 & 0.02 & Ref & & Ref & $41 \cdot 1$ & 0.88 & Ref & & Ref \\
\hline Mild & 4513 & 0.78 & 0.01 & 0.02 & $-0.02,0.06$ & 0.352 & 37.9 & 0.68 & $-2 \cdot 80$ & $-4.97,-0.62$ & 0.012 \\
\hline Moderate & 2409 & 0.75 & 0.02 & -0.02 & $-0.07,0.04$ & 0.504 & 39.7 & 0.99 & -1.84 & $-4 \cdot 26,0.58$ & 0.134 \\
\hline Severe & 1807 & 0.68 & 0.03 & -0.08 & $-0.14,-0.02$ & 0.015 & $37 \cdot 8$ & 1.35 & -3.53 & $-6.49,-0.56$ & 0.020 \\
\hline \multicolumn{12}{|l|}{ Wealth index } \\
\hline$Q_{1}$ - the poorest & 2639 & 0.66 & 0.03 & Ref & & Ref & 39.1 & 1.47 & Ref & & Ref \\
\hline $\mathrm{Q}_{2}$ & 2693 & 0.69 & 0.02 & 0.03 & $-0.05,0.10$ & 0.465 & $37 \cdot 8$ & 0.92 & $-1 \cdot 85$ & $-4 \cdot 89,1 \cdot 19$ & 0.228 \\
\hline $\mathrm{Q}_{3}$ & 2665 & 0.77 & 0.02 & 0.11 & $0.03,0.19$ & 0.011 & $39 \cdot 0$ & 1.02 & -0.15 & $-3.51,3.20$ & 0.926 \\
\hline $\mathrm{Q}_{4}$ & 2461 & 0.79 & 0.02 & 0.12 & $0.05,0.20$ & 0.001 & $39 \cdot 4$ & 0.93 & 0.21 & $-2.94,3.35$ & 0.897 \\
\hline$Q_{5}-$ the richest & 2244 & 0.81 & 0.02 & $0 \cdot 15$ & $0.07,0.23$ & $<0.0001$ & $40 \cdot 3$ & 1.00 & $1 \cdot 16$ & $-2 \cdot 16,4 \cdot 47$ & 0.489 \\
\hline \multicolumn{12}{|l|}{ Ethnicity } \\
\hline Mestizo & 10268 & 0.76 & 0.01 & Ref & & Ref & 39.7 & 0.54 & Ref & & Ref \\
\hline Black/Afro-descendant & 1269 & 0.68 & 0.08 & -0.08 & $-0.25,0.09$ & 0.335 & 33.1 & $2 \cdot 90$ & $-6 \cdot 36$ & $-11 \cdot 6,-1.07$ & 0.019 \\
\hline Indigenous & 1067 & 0.75 & 0.03 & -0.01 & $-0.08,0.05$ & 0.662 & 38.6 & 1.44 & -1.57 & $-4 \cdot 39,1 \cdot 24$ & 0.268 \\
\hline \multicolumn{12}{|l|}{ Area } \\
\hline Urban & 9346 & 0.77 & 0.01 & Ref & & Ref & 39.3 & 0.55 & Ref & & \\
\hline Rural & 3356 & 0.72 & 0.02 & -0.05 & $-0.10,0.00$ & 0.058 & $39 \cdot 2$ & 1.03 & -0.02 & $-2 \cdot 18,2 \cdot 13$ & \\
\hline \multicolumn{12}{|l|}{ Region } \\
\hline Central & 3104 & 0.86 & 0.02 & Ref & & Ref & 39.9 & 0.82 & Ref & & Ref \\
\hline Atlantic & 2250 & 0.57 & 0.02 & -0.29 & $0.34,-0.24$ & $<0.0001$ & $35 \cdot 4$ & 1.09 & -3.88 & $-6 \cdot 52,-1 \cdot 24$ & 0.005 \\
\hline Eastern & 2208 & 0.82 & 0.02 & -0.03 & $-0.09,0.02$ & 0.248 & $43 \cdot 8$ & $1 \cdot 27$ & 4.00 & $1.01,6.99$ & 0.010 \\
\hline Pacific & 1592 & 0.78 & 0.03 & -0.08 & $-0.16,-0.07$ & 0.032 & $35 \cdot 7$ & 0.97 & -3.92 & $-6 \cdot 36,-1.48$ & 0.002 \\
\hline Bogotá & 853 & 0.79 & 0.02 & -0.07 & $-0.12,-0.02$ & 0.013 & $45 \cdot 1$ & 1.41 & $6 \cdot 27$ & $3.00,9.53$ & $<0.0001$ \\
\hline Amazon/Orinoquia & 2695 & 0.78 & 0.02 & -0.07 & $-0.13,-0.02$ & 0.009 & $35 \cdot 8$ & 1.40 & -3.50 & $-6.65,-0.34$ & 0.031 \\
\hline
\end{tabular}

ENSIN-2015, Encuesta Nacional de la Situación Nutricional en Colombia-2015 (National Survey of the Nutritional Situation of Colombia-2015); Ref, reference; H/A, height for age; $\mathrm{Q}$, quintile.

* Based on BMI equivalents according to the International Obesity Task Force.

† Based on the Latin American and Caribbean Food Security (ELCSA) Scale.

according to the ENSIN is decreasing: 0.57 in 2010 and 0.49 in 2015. At these doses, the risk for developing colorectal or other cancers is very low ${ }^{(38-40)}$; red meat is a risk factor for the development of cancer when the dose reaches average amounts greater than $100 \mathrm{~g} / \mathrm{d}$ and a frequency of one or more times per $\mathrm{d}^{(39-43)}$. According to the Colombian Cattle Ranching Association (Federación Colombiana de Ganaderos (Fedegan)), in 2015, the consumption of beef among the general population was $19 \cdot 1 \mathrm{~kg}$ per capita, while the consumption of pork was $7 \cdot 8 \mathrm{~kg}$ per capita. The amount of beef, as well as its frequency, has been decreasing (it was $18.6 \mathrm{~kg}$ in 2017) but pork consumption is increasing $(9.4 \mathrm{~kg}$ per capita) ${ }^{(44)}$. With this in mind, policies that tend to increase red meat consumption are useful to increase SF levels and do not generate cancer risk.

Due to their amino-acid content and bioavailability, eggs are among the best sources of protein ${ }^{(39)}$. In the $1990 \mathrm{~s}$, and even at the beginning of the 21 st century, their consumption was questioned for their cholesterol content - between 300 and $400 \mathrm{mg}$ per $100 \mathrm{~g}$ - even though there is not enough evidence to state that dietary cholesterol is a risk factor for the development of $\mathrm{CVD}^{(45-48)}$. According to the National Poultry Farmers Fund of Colombia (Fondo Nacional de Avicultores de Colombia) and the National Poultry Fund (Fondo 
Table 3. Partial regression coefficients ( $\beta)$, crude and adjusted, between serum ferritin $(\gamma)$ and red meat consumption $\left(X_{I}\right)$ (times/d) in a population between 5 and 17 years of age, Colombia, ENSIN-2015

\begin{tabular}{|c|c|c|c|c|c|c|}
\hline \multirow[b]{2}{*}{ Variable } & \multicolumn{3}{|c|}{ Crude } & \multicolumn{3}{|c|}{ Adjusted difference } \\
\hline & $\beta^{*}$ & $95 \% \mathrm{Cl}$ & $P$ & $\beta \dagger$ & $95 \% \mathrm{Cl}$ & $P$ \\
\hline Total & $3 \cdot 26$ & $1.46,5.07$ & 0.001 & 2.99 & $1.18,4.73$ & \\
\hline \multicolumn{7}{|l|}{ Sex } \\
\hline Male & 4.52 & $1.90,7 \cdot 14$ & 0.001 & Ref & Ref & Ref \\
\hline Female & 1.92 & $-0.41,4.24$ & 0.104 & -2.57 & $-5.92,0.78$ & 0.131 \\
\hline \multicolumn{7}{|l|}{ Age group (years) } \\
\hline Children $(5-10)$ & 3.05 & $0.05,6.04$ & 0.046 & Ref & Ref & Ref \\
\hline Adolescents (11-17) & 3.44 & $1.03,5.85$ & 0.006 & -0.23 & $-4.11,3.67$ & 0.908 \\
\hline \multicolumn{7}{|l|}{ Age (years) } \\
\hline $5-8$ & 3.74 & $0.60,6.89$ & 0.020 & 1.73 & $-2 \cdot 63,6 \cdot 10$ & 0.430 \\
\hline $9-11$ & $2 \cdot 15$ & $-1 \cdot 54,5 \cdot 83$ & 0.248 & Ref & Ref & Ref \\
\hline $12-15$ & 3.89 & $0.44,7.34$ & 0.028 & $1 \cdot 26$ & $-3 \cdot 85,6 \cdot 37$ & 0.624 \\
\hline $16-17$ & $2 \cdot 53$ & $-1 \cdot 83,6 \cdot 88$ & 0.250 & -0.50 & $-6.01,5.92$ & 0.987 \\
\hline \multicolumn{7}{|l|}{ Stunted growth } \\
\hline No & 3.36 & $1 \cdot 48,5 \cdot 23$ & 0.001 & Ref & Ref & Ref \\
\hline Yes $(z<2)$ & 2.07 & $-3.22,7.37$ & 0.436 & -1.44 & $-7 \cdot 24,4 \cdot 35$ & 0.620 \\
\hline \multicolumn{7}{|l|}{ Nutritional status (BMI) $\ddagger$} \\
\hline No & $2 \cdot 71$ & $0.75,4.66$ & 0.008 & $-2 \cdot 80$ & $-9.41,3.80$ & 0.399 \\
\hline Overweight ( $\left.\geq 25 \mathrm{~kg} / \mathrm{m}^{2}\right)$ & 4.94 & $-0.95,10.83$ & 0.098 & Ref & Ref & Ref \\
\hline Obese $\left(\geq 30 \mathrm{~kg} / \mathrm{m}^{2}\right)$ & $6 \cdot 21$ & $-2 \cdot 22,14.65$ & 0.133 & 0.96 & $-9 \cdot 78,11.69$ & 0.859 \\
\hline \multicolumn{7}{|l|}{ Food insecurity§ } \\
\hline No & 3.88 & $1.01,6.74$ & 0.009 & 0.58 & $-5.83,6.99$ & 0.857 \\
\hline Mild & $1 \cdot 75$ & $-1 \cdot 38,4.89$ & 0.267 & -1.64 & $-7 \cdot 65,4.36$ & 0.586 \\
\hline Moderate & $4 \cdot 20$ & $-1.07,9.47$ & 0.116 & Ref & Ref & Ref \\
\hline Severe & $3 \cdot 10$ & $-1.33,7.52$ & 0.165 & -1.84 & $-8 \cdot 99,5 \cdot 31$ & 0.609 \\
\hline \multicolumn{7}{|l|}{ Wealth index } \\
\hline$Q_{1}-$ the poorest & 5.95 & $2 \cdot 05,9 \cdot 84$ & 0.004 & 4.59 & $-1 \cdot 71,10 \cdot 89$ & 0.151 \\
\hline $\mathrm{Q}_{2}$ & $2 \cdot 98$ & $0 \cdot 16,5 \cdot 80$ & 0.039 & $1 \cdot 77$ & $-3 \cdot 75,7 \cdot 29$ & 0.524 \\
\hline $\mathrm{Q}_{3}$ & 4.91 & $1 \cdot 37,8 \cdot 44$ & 0.008 & $3 \cdot 39$ & $-2 \cdot 12,8.90$ & 0.223 \\
\hline $\mathrm{Q}_{4}$ & $1 \cdot 19$ & $-3 \cdot 22,5 \cdot 60$ & 0.588 & Ref & Ref & Ref \\
\hline$Q_{5}$ - the richest & 1.04 & $-3 \cdot 65,5 \cdot 72$ & 0.651 & -0.25 & $-7 \cdot 04,6 \cdot 54$ & 0.942 \\
\hline \multicolumn{7}{|l|}{ Ethnicity } \\
\hline Mestizo & 3.06 & $1 \cdot 10,5 \cdot 02$ & 0.003 & -0.19 & $-6 \cdot 73,6 \cdot 35$ & 0.953 \\
\hline Black/Afro-descendant & $4 \cdot 23$ & $-2.06,10.53$ & 0.170 & -0.11 & $-9 \cdot 05,8 \cdot 82$ & 0.980 \\
\hline Indigenous & $3 \cdot 34$ & $-3.89,10.57$ & 0.334 & Ref & Ref & Ref \\
\hline \multicolumn{7}{|l|}{ Area } \\
\hline Urban & $2 \cdot 19$ & $-0.27,4.65$ & 0.080 & Ref & Ref & Ref \\
\hline Rural & 4.89 & $2 \cdot 11,7 \cdot 67$ & 0.001 & 3.23 & $-0.53,6.99$ & 0.091 \\
\hline \multicolumn{7}{|l|}{ Region } \\
\hline Central & 4.50 & $2 \cdot 10,6 \cdot 89$ & 0.001 & $1 \cdot 34$ & $-4.88,7.56$ & 0.669 \\
\hline Atlantic & 1.56 & $-4 \cdot 05,7 \cdot 17$ & 0.558 & $-1 \cdot 25$ & $-9.00,6.51$ & 0.749 \\
\hline Eastern & $2 \cdot 84$ & $-1.87,7.56$ & 0.218 & -1.33 & $-8.50,5.84$ & 0.712 \\
\hline Pacific & -0.29 & $-4 \cdot 81,4 \cdot 24$ & 0.892 & $-3 \cdot 41$ & $-10.57,3.74$ & 0.344 \\
\hline Bogotá & $-3 \cdot 38$ & $\mathrm{Nd}$ & $\mathrm{Nd}$ & $-6 \cdot 45$ & $-17 \cdot 64,4 \cdot 74$ & 0.253 \\
\hline Amazon & $3 \cdot 10$ & $-4.38,10.58$ & 0.360 & Ref & Ref & Ref \\
\hline
\end{tabular}

ENSIN-2015, Encuesta Nacional de la Situación Nutricional en Colombia-2015 (National Survey of the Nutritional Situation of Colombia-2015); Ref, reference; Q, quintile; Nd, no data.

${ }^{*}$ Partial regression coefficient achieved in a simple linear regression model.

$\dagger$ Partial regression coefficient achieved in a multiple linear regression model, where the dependent variable is the serum ferritin level ( $\mu / l)$, and the main explanatory variable is the frequency/d of red meat consumption. The model was adjusted for sex, age, nutritional status, level of food insecurity in the household, wealth index, ethnicity, and geographical area and region.

$\ddagger$ Based on BMl equivalents according to the International Obesity Task Force.

$\S$ Based on the Latin American and Caribbean Food Security (ELCSA) Scale.

Nacional Avícola (FENAVI)), the egg industry has been growing steadily in the last 9 years. In 2017, a figure of 279 units per capita consumed by the general population was reported and an increase of fifteen units was expected for $2018^{(49)}$. According to the ENSIN, the frequency/d in this age group also increased, going from 0.69 in 2010 to 0.76 in 2015.

In Colombia, as in many parts of the world, anaemia and $\mathrm{Fe}$ deficiency have been treated, among other interventions, with the fortification of wheat flour and other grains. According to Decree 1944 of October 28, 1996, wheat flour must be fortified with vitamin $B_{1}$, vitamin $B_{2}$, niacin, folic acid and Fe. Each $\mathrm{kg}$ of wheat flour should have at least $44 \mathrm{mg}$ of Fe through ferrous fumarate ${ }^{(50)}$. In Colombia, only wheat flour is enriched. The consumption of eggs and red meat is visible, that of wheat flour is invisible. Flour is found in preparations such as bread, cakes, sauces, etc., which makes it difficult to estimate the prevalence, frequency/d and the amount consumed. Also, in Colombia, other situations make measurement even more difficult, e.g. there is the smuggling of flour at the borders; so much of what is consumed is not enriched. 
Table 4. Partial regression coefficients ( $\beta$ ), crude and adjusted, between serum ferritin $(\gamma)$ and egg consumption ( $X I)$ (times/d) in a population between 5 and 17 years of age, Colombia, ENSIN-2015

\begin{tabular}{|c|c|c|c|c|c|c|}
\hline \multirow[b]{2}{*}{ Variable } & \multicolumn{3}{|c|}{ Crude } & \multicolumn{3}{|c|}{ Adjusted difference $†$} \\
\hline & $\beta^{*}$ & $95 \% \mathrm{Cl}$ & $P$ & $\beta$ & $95 \% \mathrm{Cl}$ & $P$ \\
\hline Total & $2 \cdot 66$ & $1 \cdot 10,4 \cdot 21$ & & $2 \cdot 47$ & $1.01,3.94$ & \\
\hline \multicolumn{7}{|l|}{ Sex } \\
\hline Male & 3.35 & $1.08,5.62$ & 0.004 & Ref & Ref & Ref \\
\hline Female & 1.92 & $0.16,3.68$ & 0.003 & $-1 \cdot 16$ & $-3.94,1.62$ & 0.407 \\
\hline \multicolumn{7}{|l|}{ Age group (years) } \\
\hline Children (5-10) & $2 \cdot 82$ & $0.61,5.04$ & 0.013 & Ref & Ref & Ref \\
\hline Adolescents (11-17) & $2 \cdot 55$ & $0.40,4.69$ & 0.021 & 0.02 & $-3.00,3.05$ & 0.989 \\
\hline \multicolumn{7}{|l|}{ Age (years) } \\
\hline $5-8$ & 2.95 & $0.45,5.44$ & 0.022 & Ref & Ref & Ref \\
\hline $9-11$ & $2 \cdot 82$ & $-0 \cdot 15,5 \cdot 80$ & 0.062 & -0.31 & $-4.08,3.45$ & 0.869 \\
\hline $12-15$ & $4 \cdot 16$ & $0.99,7.32$ & 0.011 & 0.97 & $-2 \cdot 95,4 \cdot 89$ & 0.622 \\
\hline $16-17$ & $-1 \cdot 12$ & $-4 \cdot 10,1 \cdot 85$ & 0.453 & -3.55 & $-7.31,0.21$ & 0.064 \\
\hline \multicolumn{7}{|l|}{ Stunted growth } \\
\hline No & $2 \cdot 91$ & $1.34,4.49$ & $<0.0001$ & Ref & Ref & Ref \\
\hline Yes $(z<2)$ & -0.31 & $-4 \cdot 87,4 \cdot 25$ & 0.891 & $-3 \cdot 78$ & $-8.02,0.46$ & 0.080 \\
\hline \multicolumn{7}{|l|}{ Nutritional status (BMI)‡ } \\
\hline No & $3 \cdot 19$ & $1.53,4.85$ & $<0.0001$ & $3 \cdot 85$ & $-4 \cdot 79,12 \cdot 49$ & 0.376 \\
\hline Overweight $\left(\geq 25 \mathrm{mg} / \mathrm{m}^{2}\right)$ & -0.64 & $-5 \cdot 28,3.99$ & 0.782 & 0.34 & $-9 \cdot 46,10 \cdot 14$ & 0.945 \\
\hline Obese $\left(\geq 30 \mathrm{~kg} / \mathrm{m}^{2}\right)$ & -0.92 & $-10 \cdot 28,8 \cdot 44$ & 0.837 & Ref & Ref & Ref \\
\hline \multicolumn{7}{|l|}{ Food insecurity§ } \\
\hline No & 3.27 & $0 \cdot 04,6 \cdot 51$ & 0.047 & 2.93 & $-1 \cdot 90,7 \cdot 76$ & 0.230 \\
\hline Mild & 1.85 & $-0.32,4.02$ & 0.094 & $2 \cdot 16$ & $-2 \cdot 24,6 \cdot 56$ & 0.331 \\
\hline Moderate & 4.92 & $1 \cdot 63,8 \cdot 21$ & 0.004 & 4.62 & $-0.30,9.55$ & 0.065 \\
\hline Severe & 0.12 & $-3.82,4.06$ & 0.952 & Ref & Ref & Ref \\
\hline \multicolumn{7}{|l|}{ Wealth index } \\
\hline $\mathrm{Q}_{1}$ - the poorest & $1 \cdot 81$ & $-2 \cdot 21,5 \cdot 84$ & 0.370 & -0.69 & $-5 \cdot 50,4 \cdot 11$ & 0.774 \\
\hline $\mathrm{Q}_{2}$ & 0.69 & $-2 \cdot 17,3 \cdot 54$ & 0.632 & $-1 \cdot 80$ & $-5 \cdot 95,2 \cdot 36$ & 0.391 \\
\hline $\mathrm{Q}_{3}$ & $2 \cdot 56$ & $-0.37,5.50$ & 0.085 & Ref & Ref & Ref \\
\hline $\mathrm{Q}_{4}$ & $2 \cdot 03$ & $-0.77,4.82$ & 0.150 & -0.19 & $-4.07,3.68$ & 0.921 \\
\hline $\mathrm{Q}_{5}$ - the richest & 4.77 & $0.74,8.79$ & 0.022 & $2 \cdot 27$ & $-2.53,7.06$ & 0.348 \\
\hline \multicolumn{7}{|l|}{ Ethnicity } \\
\hline Mestizo & $2 \cdot 87$ & $1 \cdot 27,4 \cdot 47$ & 0.001 & $1 \cdot 12$ & $-3 \cdot 28,5 \cdot 54$ & 0.611 \\
\hline Black/Afro-descendant & -2.04 & $-7 \cdot 38,3 \cdot 31$ & 0.429 & -3.94 & $-10 \cdot 65,2 \cdot 78$ & 0.246 \\
\hline Indigenous & 1.45 & $-2 \cdot 95,5 \cdot 84$ & 0.487 & Ref & Ref & Ref \\
\hline \multicolumn{7}{|l|}{ Area } \\
\hline Urban & $3 \cdot 22$ & $1.39,5.06$ & 0.001 & Ref & Ref & Ref \\
\hline Rural & 1.27 & $-1.54,4.09$ & 0.369 & -1.71 & $-4.98,1.56$ & 0.301 \\
\hline \multicolumn{7}{|l|}{ Region } \\
\hline Central & $1 \cdot 25$ & $-0.85,3.35$ & 0.222 & $2 \cdot 38$ & $-0.89,5.64$ & 0.150 \\
\hline Atlantic & 0.07 & $-3.94,4.08$ & 0.970 & 0.65 & $-3 \cdot 89,5 \cdot 20$ & 0.774 \\
\hline Eastern & 1.55 & $-1 \cdot 91,5 \cdot 01$ & 0.354 & $2 \cdot 42$ & $-1.53,6.38$ & 0.226 \\
\hline Pacific & 0.63 & $-3.24,4.51$ & 0.727 & 1.99 & $-2 \cdot 37,6 \cdot 35$ & 0.365 \\
\hline Bogotá & $12 \cdot 88$ & $\mathrm{Nd}$ & $\mathrm{Nd}$ & 13.40 & $5 \cdot 51,21 \cdot 30$ & 0.001 \\
\hline Amazon & -0.59 & $-3.95,2.78$ & 0.693 & Ref & Ref & Ref \\
\hline
\end{tabular}

ENSIN-2015, Encuesta Nacional de la Situación Nutricional en Colombia-2015 (National Survey of the Nutritional Situation of Colombia-2015); Ref, reference; Q, quintile; Nd, no data.

${ }^{*}$ Partial regression coefficient achieved in a simple linear regression model.

$\dagger$ Partial regression coefficient achieved in a multiple linear regression model, where the dependent variable is the serum ferritin level ( $\mu / l)$, and the main explanatory variable is the frequency/d of egg consumption. The model was adjusted for sex, age, nutritional status, level of food insecurity in the household, wealth index, ethnicity, and geographical area and region.

$\ddagger$ Based on BMI equivalents according to the International Obesity Task Force.

$\S$ Based on the Latin American and Caribbean Food Security (ELCSA) Scale.

Enriched flour does not necessarily contain the same amounts, since the standard establishes a minimum level but is not mandatory, so some producers add ferrous fumarate above the minimum level. Therefore, it is not possible to introduce a non-haem indicator in the analysis.

Although many countries in the world fortify grains with $\mathrm{Fe}$, few evaluate the impact of this intervention; Colombia is one of them. However, evidence consistently suggests that fortification increases SF levels, but not $\mathrm{Hb}_{\text {levels }}{ }^{(51)}$. The prevalence of anaemia and Fe deficiency in the Colombian population and in the age group studied here suggests that, while fortification of wheat flour is important as a public health measure, it is not sufficient, nor is it the only one that should be considered. Since the percentage of bioavailability of haem $\mathrm{Fe}$ is three times higher than that of non-haem Fe and, once consumed, its absorption can be increased up to four times if it is accompanied by acidic juices ${ }^{(52)}$, dietary interventions based on the consumption of red meat and eggs within a comprehensive strategy consistent with Food-Based Dietary Guidelines, which address other public health problems such as childhood obesity, should be considered ${ }^{(21)}$. Energy expenditure should be decisive in these strategies, 


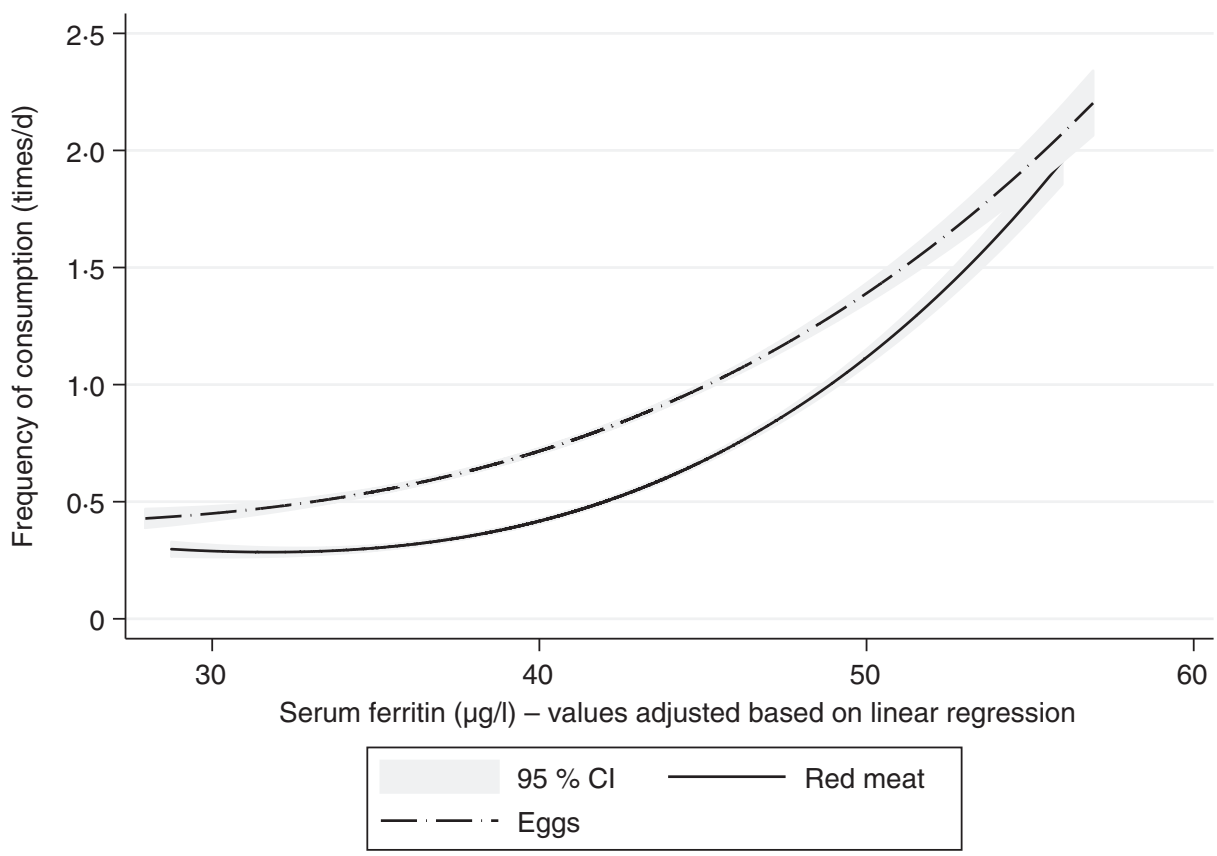

Fig. 2. Adjusted serum ferritin levels and frequency of red meat and egg consumption (times/d). Colombia, ENSIN-2015 (Encuesta Nacional de la Situación Nutricional en Colombia-2015; National Survey of the Nutritional Situation of Colombia-2015).

because there is evidence of excessive protein consumption in children in Colombia ${ }^{(6)}$. In addition, red meat and eggs are part of the traditional consumption pattern, which actually protects children from excess weight in Colombia ${ }^{(8)}$.

In diets rich in cereals of vegetarians, the addition of eggs showed that due to phosphovitin contained in the yolk, $\mathrm{Fe}$ absorption may be decreased between 16 and $50 \%{ }^{(53)}$. However, in Colombia, eggs are not only consumed for Fe, but they are also the main source of protein of high biological value and the most economical. The prevalence of vegetarianism in Colombia is less than $1 \%{ }^{(10)}$, and in any case, these findings in vitro would be in favour of the association reported here, because if this effect were important in Colombia, it would mitigate the associations reported.

Finally, all structural aspects that directly or indirectly constitute barriers for red meat and eggs to reach the plates of children and the Colombian population, in general, or, specifically, to the detriment of their availability and consumption, both in quantity and frequency/d, are against public health. Discouraging rural development, taxing the basic food basket and foods that are traditionally consumed by the population, the armed conflict, disinformation about the dietary properties of food and their relationship with chronic disease, the inability to control borders and allow contraband, poor phytosanitary control in the regions, the lack of energy infrastructure and other reasons external to the nutrition sector are the structural aspects referred to.

\section{Scope and limitations of the study}

Usual food consumption is stable in the medium and long term. The estimates made by the ENSIN-2005, and more recently by Federación Colombiana de Ganaderos (Fedegan) and Fondo Nacional Avícola (FENAVI), allow approximating reliably the amount (g) consumed by children. The frequency (times/d) estimated with an FFQ is the best mechanism to calculate the usual intake; therefore, the correlation found between SF levels and red meat and egg consumption with ENSIN-2015 data is plausible and also valid. The ENSIN-2015 is still being developed; future results of the 24-h recall, which allow incorporating the amount $(\mathrm{g})$ of red meat and eggs consumed, will facilitate the understanding of the correlation between red meat and egg consumption with SF levels and the design of population-based dietary interventions. The results presented here on frequency/d of consumption can be used as a baseline to evaluate the impact of policies aimed at increasing red meat and egg consumption.

\section{Acknowledgements}

The present study received no specific grant from any funding agency, commercial or not-for-profit sectors.

O. F. H. and J. N. B. designed the study, obtained the databases of the ICBF (Instituto Colombiano de Bienestar Familiar; Colombian Family Welfare Institute), prepared the databases and conducted and led statistical analyses. O. F. H., J. N. B. and M. del P. Z. interpreted the results, prepared, reviewed and wrote the manuscript that was finally submitted. All authors reviewed the manuscript and approved the final version.

The authors declare that they have no conflicts of interest.

\section{References}

1. Bowman B \& Russell R (editors) (2003) Current Knowledge of Nutrition. Scientific and Technical Publication, no. 592. Washington: PAHO.

2. Garry PJ, Hunt WC \& Baumgartner RN (2000) Effects of iron intake on iron stores in elderly men and women: longitudinal and cross-sectional results. J Am Coll Nutr 19, 262-269. 
3. Nel E, Kruger HS, Baumgartner J, et al.. (2015) Differential ferritin interpretation methods that adjust for inflammation yield discrepant iron deficiency prevalence. Matern Child Nutr 11, Suppl. 4, 221-228.

4. Nairz M, Theurl I, Wolf D, et al. (2016) Iron deficiency or anemia of inflammation? Wien Med Wochenschr 166, 411-423.

5. Food and Nutrition Board, Institute of Medicine, National Academies (2018) Dietary Reference Intakes (DRIs), Recommended Dietary Allowances and Adequate Intakes, Vitamins. https://www.ncbi.nlm. nih.gov/books/NBK56068/table/summarytables.t2/?report=objectonly (accessed March 2020).

6. Herrán O, DelCastillo S \& Patiño GA (2017) Exceso de proteínas en la pobreza: la paradoja del exceso de peso en niños colombianos (Excess protein in poverty: the paradox of excess weight in Colombian children). Rev Chil Nutr 44, 45-56.

7. Herrán OF, Patiño GA \& DelCastillo SE (2016) La transición alimentaria y el exceso de peso en adultos evaluados con base en la Encuesta de la Situación Nutricional en Colombia, 2010 (The food transition and excess weight in adults evaluated based on the Survey of the Nutritional Situation in Colombia, 2010). Biomédica 36, 109-120.

8. Ocampo PR, Prada GE \& Herrán OF (2014) Patrones de consumo alimentario y exceso de peso infantil; encuesta de la situación nutricional en Colombia, 2010 (Food consumption patterns and excess childhood weight; a survey of the nutritional situation in Colombia, 2010). Rev Chil Nutr 41, 351-359.

9. Profamilia, Instituto Nacional de Salud, Universidad de Antioquia, OPS, Instituto Colombiano de Bienestar Familiar (2005) National Survey of the Nutritional Situation of Colombia. Bogotá, DC: ICBF.

10. Ministerio de la Protección Social, Instituto Colombiano de Bienestar Familiar (2011) National Survey of the Nutritional Situation in Colombia, 2010. Bogotá, DC: ICBF.

11. Instituto Colombiano de Bienestar Familiar (2015) Colombian Food Composition Table. Bogotá, DC: ICBF.

12. Organización Mundial de la Salud (OMS) (2011) Concentraciones de hemoglobina para diagnosticar la anemia y evaluar su gravedad. WHO/NMH/NHD/MNM/11.1. VMNIS. Sistema de Información Nutricional sobre Vitaminas y Minerales (Hemoglobin concentrations to diagnose anemia and assess its severity. WHO/NMH/NHD/ MNM/11.1. VMNIS. Vitamin and Mineral Nutrition Information System). Gibebra: OMS. https://www.who.int/vmnis/indicators/ haemoglobin_es.pdf (accessed March 2020).

13. Petry N, Olofin I, Hurrell R, et al. (2016) The proportion of anemia associated with iron deficiency in low, medium, and high human development index countries: a systematic analysis of national surveys. Nutrients 8, 693-710.

14. Haas JD \& Brownlie T (2001) Iron deficiency and reduced work capacity: a critical review of the research to determine a causal relationship. J Nutr 131, 676S-690S.

15. Beard JL, Borel MJ \& Derr J (1990) Impaired thermoregulation and thyroid function in iron-deficiency anemia. Am J Clin Nutr 52, 813819.

16. Beard JL (2001) Iron biology in immune function, muscle metabolism and neuronal functioning. J Nutr 131, 568S-580S.

17. De Andrade Cairo RC, Rodrigues Silva L, Carneiro Bustani N, et al. (2014) Iron deficiency anemia in adolescents; a literature review. Nutr Hosp 29, 1240-1249.

18. Li W, Herrán OF \& Villamor E (2017) Trends in iron, zinc, and vitamin A status biomarkers among Colombian children: results from 2 nationally representative surveys. Food Nutr Bull 38, 146-157.

19. Subramaniam G \& Girish M (2015) Iron deficiency anemia in children. Indian J Pediatr 82, 558-564.

20. DPN (Departamento Nacional de Planeación) (2015) Plan Nacional de Desarrollo, 2014-2018 (National Development Plan, 2014-2018). Bogotá, Colombia: Departamento Nacional de Planeación.

21. Instituto Colombiano de Bienestar Familiar (ICBF) (2015) Guias Alimentarias Basadas en Alimentos: Para la Población Colombiana Mayor de 2 Años (Food Based Food Guides: For the Colombian Population Over 2 Years). ICBF. Bogotá, Colombia: ICBF.
22. Bautista LE, Herrán OF \& Pryer JA (2005) Development and simulated validation of a food-frequency questionnaire for the Colombian population. Public Health Nutr 8, 181-188.

23. Herrán OF \& Ardila MF (2006) Validity and reproducibility of two semi-quantitative alcohol frequency questionnaires for the Colombian population. Public Health Nutr 9, 763-770.

24. Cole TJ, Bellizzi MC, Flegal KM, et al. (2000) Establishing a standard definition for child overweight and obesity worldwide: international survey. $\operatorname{Br}$ Med J 320, 1240-1243.

25. Cole TJ \& Lobstein T (2012) Extended international (IOTF) body mass index cut-offs for thinness, overweight and obesity. Pediatr Obes 7, 284-294.

26. Rutstein SO (2008) The DHS Wealth Index: Approaches for Rural and Urban Areas. Calverton, MD: Macro International.

27. Gutierres de Pineda V (1994) Familia y cultura en Colombia (Family and Culture in Columbia), 3rd ed. Medellín, Colombia: Universidad de Antioquia.

28. StataCorp (2015) Stata Statistical Software: Release 14. College Station, TX: StataCorp LP.

29. Asociación Médica Mundial (2015) Declaración de Helsinki Principios éticos para las investigaciones médicas en seres humanos (Declaration of Helsinki - Ethical principles for medical research in humans). https://www.wma.net/es/policies-post/declaracion-dehelsinki-de-la-amm-principios-eticos-para-las-investigaciones-medicas-en-seres-humanos/ (accessed November 2018).

30. Ministerio de Salud (Colombia) (1993) Resolución Numero 8430 de 1993 (Resolution number 8430 of 1993). https://www.minsalud. gov.co/sites/rid/Lists/BibliotecaDigital/RIDE/DE/DIJ/ RESOLUCION-8430-DE-1993.PDF (accessed November 2018).

31. Jara Navarro MI (2008) Hambre, desnutrición y anemia: una grave situación de salud pública (Hunger, malnutrition and anaemia: a serious public health situation). Rev Gerenc Polit Salud 7, 7-10.

32. von Grebmer K, Torero M, Olofinbiyi T, et al. (2011) Índice global del hambre. El desafío del hambre: domar la volatilidad excesiva y los picos de los precios alimentarios (Global hunger index. The hunger challenge: control excessive volatility and spikes in food prices). Washington, DC: IFPRI. http://cdm15738.contentdm. oclc.org/utils/getfile/collection/p15738coll2/id/124875/filename/124876.pdf (accessed November 2014).

33. Herrán OF, Patiño GA \& DelCastillo SE (2015) Desigualdad y nutrición: encuesta de la situación nutricional en Colombia, 2010 (Inequality and nutrition: survey of the nutritional situation in Colombia, 2010). Rev Bras Saude Mater Infant 15, 401-412.

34. Programa de las Naciones Unidas para el Desarrollo (PNUD) (2013) Informe de Desarrollo Humano, 2013 (Human Development Report, 2013). New York: PNUD.

35. DNP, Consejo Nacional de Política Económica y Social (2007) National Food and Nutrition Security Policy, CONPES 113. Bogotá, DC: DNP.

36. FAO, OSAN (2014) Aproximación a los determinantes de la doble carga nutricional en Colombia (Approach to the Determinants of the Double Nutritional Burden in Colombia). Bogotá, DC: Food and Agriculture Organization of the United Nations.

37. Latham MC (2002) Nutrición humana en el mundo en desarrollo (Human nutrition in the developing world). http://www.fao.org/docrep/006/w0073s/w0073s00.htm\#Contents (accessed November 2018).

38. De Vries E, Quintero DC, Henríquez-Mendoza G, et al. (2017) Population attributable fractions for colorectal cancer and red and processed meats in Colombia - a macro-simulation study. Colombia Med 48, 64-69.

39. Bouvard V, Loomis D, Guyton KZ, et al. (2015) Carcinogenicity of consumption of red and processed meat. Lancet Oncol16, 1599-1600.

40. Ministerio de Salud y Protección Social (2015) Riesgo de cáncer por consumo de carnes es bajo en Colombia. Minsalud. Boletín de Prensa No 289 de 2015 (Cancer risk due to meat consumption is low in Colombia. Minsalud Press release no. 289 of 2015). https://www.minsalud.gov.co/Paginas/Riesgo-de-cáncer-por-consumo-de-carnes-es-bajo-en-Colombia.aspx (accessed July 2018). 
41. Cancer Council (2018) Meat and cancer. Cancer Council NSW. https://www.cancercouncil.com.au/21639/cancer-prevention/ diet-exercise/nutrition-diet/fruit-vegetables/meat-and-cancer/? $\mathrm{pp}=36593 \& \mathrm{cc}=8125 \& \& \mathrm{ct}=35$ (accessed November 2018).

42. World Health Organization \& Unión Internacional Contra el Cáncer (2005) Acción mundial contra el cancer (Global action against cancer). http://www.who.int/cancer/media/AccionMundialCancerfull.pdf (accessed October 2018).

43. World Health Organization (2018) Cáncer (Cancer). http://www.who. int/mediacentre/factsheets/fs297/es/ (accessed October 2018).

44. Federación Colombiana de Ganaderos (2018) Consumo|Fedegan. Estadísticas de consume (Consumption|Fedegan. consumption statistics). https://www.fedegan.org.co/estadisticas/consumo-0 (accessed November 2018).

45. Berger S, Raman G, Vishwanathan R, et al. (2015) Dietary cholesterol and cardiovascular disease: a systematic review and meta-analysis. Am J Clin Nutr 102, 276-294.

46. Bautista LE, Herrán OF \& Serrano C (2001) Effects of palm oil and dietary cholesterol on plasma lipoproteins: results from a dietary crossover trial in free-living subjects. Eur J Clin Nutr 55, 748-754.

47. Zárate A, Manuel-Apolinar L, Basurto L, et al. (2016) Colesterol y aterosclerosis. Consideraciones históricas y tratamiento (Cholesterol and atherosclerosis. Historical considerations and treatment). Arch Cardiol Méx 86, 163-169.

48. Clayton ZS, Fusco E \& Kern M (2017) Egg consumption and heart health: a review. Nutrition 37, 79-85.

49. FENAVI (Federación Nacional de Avicultores de Colombia. Fondo Nacional Avicola) (2018) Huevo en cifras (Eggs in figures). http://fenavi.org/centro-de-noticias/noticia-destacada-del-centrode-noticias/pollo-en-cifras-2/ (accessed November 2018).

50. Ministerio de Salud Publica (1996) Presidencia de la República de Colombia. DECRETO 1944 de Octubre 28 de 1996. Diario Oficial no. 42.909, de 30 de octubre de 1996 (Presidency of the Republic of Colombia. DECREE 1944 of October 28, 1996. Official Gazette no. 42.909, of October 30, 1996). https://www. icbf.gov.co/cargues/avance/docs/decreto_1944_1996.htm (accessed November 2018).

51. Pachón H (2014) Avances en la fortificación de harina de trigo a nivel global (Advances in the fortification of wheat flour globally). An Venez, Nutr 27, 31-39.

52. Callender ST, Marney SR \& Warner GT (1970) Eggs and iron absorption. Br J Haematol 19, 657-665.

53. Singh A, Bains K \& Kaur H (2016) Effect of inclusion of key foods on in vitro iron bioaccessibility in composite meals. J Food Sci Technol 53, 2033-2039. 